\title{
On trade creation and regional trade agreements: does depth matter?
}

\author{
Vincent Vicard
}

Published online: 22 April 2009

(C) Kiel Institute 2009

\begin{abstract}
Regional trade agreements (RTAs) are usually classified according to their form into four broad categories: preferential arrangements, free trade agreements, customs unions and common markets. This paper investigates whether the form/depth of RTAs matters concerning their effect on trade. I use a proper specification of the gravity model with panel data on the 1960-2000 period, which specifically control for self-selection into agreements. Results show that creating any kind of RTAs providing trade preferences to their member countries significantly increases bilateral trade. Nevertheless, their average treatment effect on bilateral trade does not significantly differ according to the depth of agreements.
\end{abstract}

Keywords Trade $\cdot$ Regionalism

JEL Classification $\mathrm{F} 10 \cdot \mathrm{F} 15$

\section{Introduction}

At the end of 2005, 158 regional trade agreements (RTAs) were in force worldwide, which makes preferential trade liberalization a prominent feature of the international trading system today. The scope and coverage of these agreements nevertheless greatly differ from one to the other, in terms of trade flows, membership as well as population involved.

\footnotetext{
V. Vicard

Paris School of Economics, University Paris I Panthéon-Sorbonne and University Paris-Dauphine,

Paris, France

V. Vicard $(\bowtie)$

Centre d'economie de la Sorbonne, 106-112, Bd de 1'hôpital, 75647 Paris Cedex 13, France

e-mail: vincent.vicard@malix.univ-paris1.fr
} 
The canonical taxonomy of RTAs, initially introduced by Balassa (1961), considers regionalism as a gradual process towards economic union, through free trade area, customs union (CU) and common market (CM). The implicit assumption behind is that more integrated arrangements provide for deeper trade integration, because each additional step of regional integration would reduce further intraregional trade costs. ${ }^{1}$ However, from a theoretical point of view, the "form/depth" of regional integration is not systematically related to the level of trade costs. If preferential arrangements (PAs) can be considered as free trade areas whose scope and coverage are less complete, a CU or a CM cannot be simply understood as further steps of economic integration. Devices of integration solely differ according to the form of trade integration: while entering a $\mathrm{CU}$ involves to give up sovereignty on trade policy to implement a common external tariff, free trade agreements (FTAs) allow member countries to keep the ability to set their tariffs vis-à-vis other partners, thanks to the use of rules of origin. Both nevertheless allow for broad preferential regimes, using different instruments of trade policy. ${ }^{2}$ The degree of trade integration is thus likely to vary according to RTAs, but not necessarily in relation with their form or the depth of political integration they entail. This paper investigates empirically whether the form/depth of RTAs determines the extent of trade creation among members.

Empirical evidence of any larger effect of deeper RTAs on the volume of regional trade is missing. Few papers even distinguish between different categories of RTAs. Two exceptions are Ghosh and Yamarik (2004b) and Kandogan (2008), who find puzzling results concerning the effect of economic integration on intraregional trade: coefficients on $\mathrm{CU}$ and $\mathrm{CM}$ membership dummies are found to be negative and significant in several specifications. However, it is worth noting that they do not control for multilateral resistance terms and, more importantly, for selfselection into RTAs. Indeed, papers on the determinants of RTAs suggest a "market for regionalism" view of regional trade integration, where countries choose their partners (Baier and Bergstrand 2004b) and the form of the RTA (Vicard 2008) according to economic and political determinants. Ex post estimations of the effect of RTAs on trade are thus likely to suffer from a selection bias, because pairs of countries which have more to gain from regional integration (or more to loose from no-agreement) are more likely to create a RTA and to choose the appropriate form of regional integration.

In this paper, I estimate a theoretically motivated gravity equation, in which the definition of RTAs is refined by introducing a distinction between different categories of RTAs according to their form/depth. Self-selection is specifically accounted for by using panel data with country-pair and country-and-time fixed effects or differenced panel with country-and-time fixed effects. Three important conclusions emerge from empirical results. First, unobservable heterogeneity affects differently the estimates of the treatment effect of different kinds of RTAs,

\footnotetext{
${ }^{1}$ For instance, Krueger (1997) argues that a free trade area cannot be more trade creating than a customs union because the former entails the implementation of rules of origin.

${ }^{2}$ For instance, the arrangements governing foreign investments under the NAFTA allow for a great mobility of capital.
} 
i.e. different country pairs choose to create different kinds of RTAs. Second, the analysis conducted in this paper confirms that all RTAs providing trade preferences to their members have a significant positive effect on bilateral trade. Third, this average treatment effect does nevertheless not differ statistically according to the depth/form of integration. Once self-selection into agreements is controlled for, creating a free trade area, a $\mathrm{CU}$ or a $\mathrm{CM}$ has the same effect on intra-regional trade.

This paper proceeds as follows. Section 2 presents the extent of preferential trade in the world. Section 3 specifies a theoretically grounded gravity equation with panel data. Results are presented in Sect. 4 and some robustness analysis in Sect. 5. Section 6 concludes the paper.

\section{Regional trade agreements in the world}

Since World War II, the coverage and scope of regional trade integration have greatly expanded, from Benelux - the first RTA created in 1947 as a CU between three countries, Belgium, Luxembourg and the Netherlands-to the 158 RTAs in force at the end of 2005, of which 125 were bilateral agreements ${ }^{3}$. These agreements range from the simple exchange of trade preferences on a limited range of products to the harmonization of policies well beyond tariffs, such as competition policies, infrastructure or standards. The creation of RTAs and their form are constrained by international rules agreed under the General Agreement on Tariffs and Trade (GATT), and now under the WTO. On the one hand, RTAs are a deviation from the principle of equal treatment defined by the "most-favored-nation" clause. Two articles frame their creation. GATT's article XXIV allows the creation of FTAs or CUs which removes tariff barriers on substantially all trade in goods. On the other hand, the so-called "enabling clause" permits PAs among developing countries, which are partial scope agreements on trade in goods. WTO rules specifically forbid the creation of PAs including developed countries.

Out of the 158 RTAs in force at the end of 2005, 2 were CMs, 11 CUs, 122 FTAs and 23 PAs. However, in terms of the number of country pairs covered, FTAs are not overwhelming since they are mostly bilateral agreements. Figure 1 depicts the evolution of country-pair membership to RTAs according to their form over the period from 1948 to 2005 . It shows that pairs of countries which are members of a RTA represent about $14 \%$ of country pairs worldwide in 2005 , from only $1 \%$ in 1948 and around $4 \%$ in the 1980s. Trade flows between RTA partners nevertheless represent one third of world trade today (World Bank 2005), which underlines that trade agreements are signed between countries trading intensively with each others.

Preferential arrangements prevail thanks in particular to the Protocol Relating to Trade Negotiations among Developing Countries signed in 1973 by 16 countries

\footnotetext{
3 The focus of this paper is on reciprocal agreements on trade in goods, so these figures do not include non-reciprocal arrangements like Generalized System of Preferences (GSP), as well as service agreements notified under the General Agreement on Trade in Services (GATS) article V.
} 

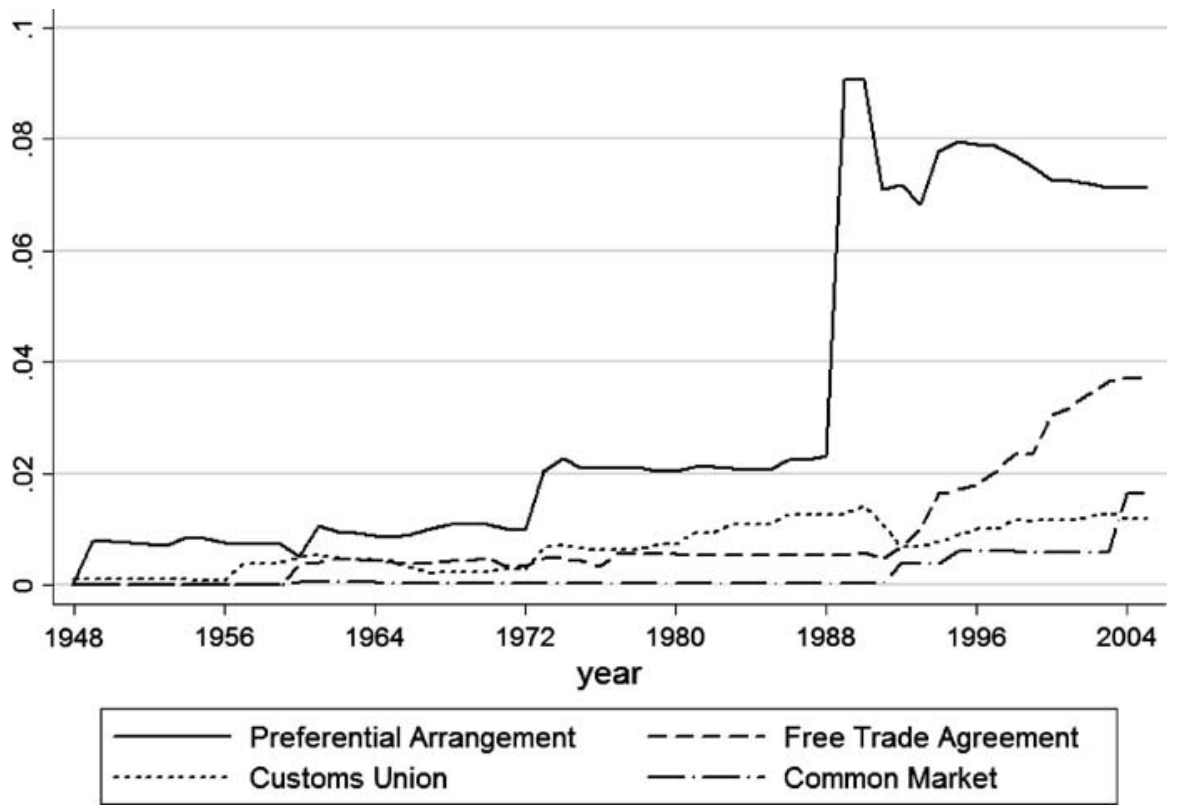

Fig. 1 Membership in RTAs (\% of the total number of country pairs in the world)

and the Global System of Trade Preferences among Developing Countries signed in 1989 by 44 countries. CU was the second more prominent form of RTAs until the 1990s, when the number and coverage of FTAs exploded, in particular with bilateral agreements signed by the European Union (EU) with Central and Eastern European countries. These agreements were nevertheless cancelled in 2004 by the accession of the ten new members to the EU, slowing down the growth path of FTA coverage in the 2000s. FTAs cover almost $4 \%$ of country pairs at end of 2005. CMs cover only two pairs of countries (under Benelux), from 1961 to the creation of the EU in 1992. This form of RTA then expands rapidly with the enlargement of the EU and ranks third in term of global country-pair coverage. The overwhelming prevalence of FTA in absolute number is dramatically reduced in terms of country-pair coverage, since CMs cover almost half of the number of country pairs under a FTA. ${ }^{4}$

A quick look at the data seems to rule out the idea of a graduate process of regional integration suggested by the traditional classification of RTAs presented above. Deeply integrated RTAs seem to be created directly as such. Indeed, out of the 18 CUs created worldwide since 1948, 14 have been created directly as such, without any intermediate step like a PA or a FTA. Out of the four remaining, two actually experienced a gradual integration, implying the creation of a PA or a FTA prior to CU, but on a short period of time [7 years for the Andean Customs Union and 5 years concerning the Caribbean Community (CARICOM)]. Besides, the West

\footnotetext{
${ }^{4}$ Fiorentino et al. (2007) moreover underline that planed RTAs are mostly bilateral FTAs.
} 
African Economic and Monetary Union (WAEMU) and the Golf Cooperation Council (GCC) have been preceded during a significant period of time by a PA before adopting common external tariffs in 1998 and 2003, respectively. Two of these CUs turned into a CM (Benelux and the EU). Another exception is the complex network of bilateral FTAs created prior to accession to the EU. All remaining FTAs and PAs did not evolve into any "deeper" form of RTA.

\section{A proper specification of the gravity equation}

The impact of RTAs on trade is mostly measured ex post using a gravity equation (Frankel 1997; Carrère 2006). This model relates bilateral trade flows to the economic size of partner countries and their distance. Additional variables are generally added to this basic specification to control for different kinds of barriers to trade. More recently, papers providing formal economic foundations for the initially atheoretical gravity equation underlined the need to account for price levels to avoid any estimation bias due to the omission of exporting and importing countries' multilateral resistance terms (Anderson and van Wincoop 2003, 2004; Feenstra 2004). Anderson and van Wincoop (2003) derive these importer's and exporter's resistance terms from a full expenditure system on a cross-section of data, and show that including country-specific fixed effects yields the same results. Baldwin and Taglioni (2006) show that, because multilateral resistance terms are likely to be time varying, such methodology do not simply translate in a panel setting. A proper specification of the gravity equation with panel data requires to include country-andtime fixed effects, which account for multilateral resistance terms varying over time. Baier and Bergstrand (2007) suggest two econometric specifications of the gravity equation to properly estimate the average treatment effect of RTAs: panel data with bilateral and country-and-time fixed effects or differenced panel data with countryand-time effects. Including bilateral fixed effects or first-differencing data removes the bias arising from the omission of unobserved variables affecting both the explained (bilateral trade) and explaining variables (RTA membership dummies) and allows to take into account the endogeneity related to self-selection, since it is mainly a cross-sectional issue. ${ }^{5}$ Indeed, Baier and Bergstrand (2004b) investigate the economic determinants of RTAs and find significant cross-section evidence that countries choose well their RTA partners, i.e. pairs of countries signing RTAs tend to share economic characteristics likely to enhance benefits from regional trade integration. They nevertheless identify only a subset of economic determinants of RTAs, which leaves a large unobserved heterogeneity. Baier and Bergstrand (2007) argue that the heterogeneity in determinants of trade, unobserved in estimations of gravity equations, is negatively associated to the decision to form a RTA. Not accounting for this heterogeneity would thus bias estimated coefficients on RTAs. On the one hand, suppose that two countries lack bilateral transport infrastructures

\footnotetext{
5 Baier and Bergstrand (2007) review alternative methods to deal with this endogeneity bias. In particular, instrumental-variable estimation and Heckman's control function approach fail to solve the endogeneity issue.
} 
or exhibit extensive domestic regulations reducing bilateral trade, and that these characteristics are unobservable to the econometrician-this creates a negative error term in the gravity equation. Expected gains from regional integration would be larger for these countries, and their government would be more likely to select into RTA, if creating a RTA not only reduces tariff barriers but also generates spillovers on regional infrastructures or leads to the harmonization of domestic regulations and standards. On the other hand, when unobserved cultural or historical characteristics shared by two countries increase at the same time trade flows and the likelihood of forming a RTA, by reducing costs related to regional integration for instance, then estimated coefficients would be biased upward. Anyway, the discussion above suggests that the decision to enter a RTA is mainly cross-sectional in nature, since it is related to the actual level of trade relative to its potential level. Recent changes in the level of trade are indeed not likely to lead to the creation of RTAs, but countries' structural characteristics are.

Yet, different kinds of RTAs are likely to be related differently to unobserved trade impediments or facilitation. As underlined by Anderson and van Wincoop (2004), in a politically fragmented world such as the international system today, international transaction costs have more to do with domestic policies (regulation, norms, property rights, infrastructures...) than traditional tariff barriers. The harmonization of these policies can be dealt with from several perspectives, using different instruments and producing different institutional frameworks. On the one hand, Anderson and Marcouiller (2002) and Blomberg and Hess (2006) respectively show that insecurity and violence are strong deterrent of trade. On the other hand, Vicard (2008) underlines that the determinants of RTAs differ according to the form/depth of integration. In particular, in a system where no supranational institution or third party can enforce property rights at the international level, country pairs experiencing interstate conflicts need mechanisms securing the continuity of trade flows in the future. Hence, CUs or CMs, which imply the creation of a strong regional institutional framework, are created between countries experiencing lots of interstates disputes, whereas international insecurity deters the formation of PAs and FTAs. Consequently, omitted security variables are likely to bias the coefficients on RTAs depending on their depth. When creating an RTA, country pairs thus choose the suitable form according to their economic, political or cultural characteristics. Accordingly, the omitted variable bias would differ between categories of RTAs.

In a cross-section of data, the only way to address such endogeneity is through the use of instrumental variables. However, no exogenous instruments are available (Magee 2003; Baier and Bergstrand 2004a). On the contrary, using panel data this endogeneity issue can be dealt with using country-pair fixed effects or by firstdifferencing the data. Because choosing between these two methods is difficult, Wooldridge (2003) recommends to report results using both. In the case of a large number of periods, the latter is likely to be more efficient when error terms exhibit substantial positive serial correlation. Unobserved factors influencing both our explaining and explained variables are likely to be changing slowly, i.e. to be serially correlated. As a robustness check, both methods are reported below, but our preferred is first-differencing the panel data. 
Formally, the following theoretically motivated specification of the gravity equation is estimated:

$$
\begin{aligned}
\ln T_{i j t}= & \beta_{0}+\beta_{1} \ln \left(\mathrm{GDP}_{i t} \mathrm{GDP}_{j t}\right)+\beta_{2} \ln \mathrm{DIST}_{i j}+\beta_{3} \text { Control }_{i j}+\beta_{4} \mathrm{PoA}_{i j t} \\
& +\beta_{5} \mathrm{PA}_{i j t}+\beta_{5} \mathrm{FTA}_{i j t}+\beta_{7} \mathrm{CU}_{i j t}+\beta_{8} \mathrm{CM}_{i j t}-\ln P_{i t}-\ln P_{j t}+t_{i j t}
\end{aligned}
$$

Controls added are common to the gravity literature, i.e. bilateral distance and dummies for common border, language and colonizer, countries ever in a colonial relationship, and landlocked countries. All these time-invariant bilateral determinants of trade are dropped when bilateral fixed effects are introduced or data are first-differenced. In the same manner, GDPs as well as multilateral resistance terms $\left(P_{i t}\right.$ and $\left.P_{j t}\right)$ are explained by country-and-time fixed effects.

The dependent variable $T_{i j t}$ is the average of the log of two-way imports. Trade data originate from the International Monetary Fund's (IMF) Direction of Trade Statistics (DoTS) database, and are assembled by Martin et al. (2008). Data on GDP are taken from the World Bank's World Development Indicators database, and geographic and historical data come from CEPII. ${ }^{6}$ Annual observations every five years over the period 1960-2000 are used, which leaves us with a sample of potentially 188 countries over nine periods, with gaps.

The average treatment effect of each kind of RTA on intra-regional trade is estimated separately, through the inclusion of four different categories of RTAs, according to their actual form (PA, FTA, CU and CM), to which Political Agreements (PoAs) are added. ${ }^{7}$ All bilateral or RTAs in force at least 1 year between 1960 and 2000 are considered. ${ }^{8}$ Unless otherwise mentioned in the sources, an agreement is assumed to be in force at the date defined in the treaty and, if not available, once the agreement has been signed and ratified. It nevertheless does not mean that all provisions of the agreement have been fully implemented at this date, since a phase-in period is often planned in the treaties. Each dummy variable is set at 1 when both countries of the pair are members of the same agreement during the year considered, i.e. at each of the nine years considered in our data set. The details of the official dates of RTAs and the dates actually used in our data set with 5-year intervals are provided in the Appendix. A pair of countries can thereby be member of only one kind of agreement a given year. The data set reports 146 RTAs over the period 1960-2000, of which 24 are coded as PAs, 103 FTAs, 17 CUs and 2 CMs, and 7 PoAs (a complete list is provided in the Appendix).

As argued above, I control for self-selection into RTAs either through firstdifferencing the data or including country-pair fixed effects. It means that only the time variation in RTA membership over the period covered by our data is accounted

\footnotetext{
6 http://www.cepii.fr/anglaisgraph/bdd/distances.htm.

7 A political agreement is defined as an organization aiming at liberalizing trade among its members but falling short of providing for tariff preferences inherent in a CM, CU, FTA or PA, such as the Generalized System of Preferences or the Everything but Arms regulation adopted by the European Union, which provide preferential or even duty free access to least developed or developing countries on a non reciprocal basis, are not considered in this paper.

8 Data are assembled from notifications to the WTO (http://www.wto.org/english/tratop_e/region_e/ region_e.htm), Foroutan (1993, 1998), Langhammer and Hiemenz (1990), Frankel (1997), Machlup (1977) and other public sources.
} 
for, i.e. the effect of entering or leaving a RTA. In this specification, the coefficients on the membership dummies can be interpreted as the average treatment effect of entering in each kind of RTAs. For instance, the formation of the European Communities by the initial six members is not captured by the coefficient on the $\mathrm{CU}$ dummy since it occurred before the beginning of our time period, but the accession of new members and the exit of all members from the CU agreement to create a CM from 1992 on are. Thus, for the country pairs member of a preexisting CU, the coefficient on the CM dummy captures the effect of entering a CM, while not being member of a CU agreement anymore (the CU dummy is set at 0 for EU countries from 1992 on).

\section{Results}

Results are reported in Table 1. The first two columns present estimates of the traditional gravity equation, when only time fixed effects (column 1) or countryand-time fixed effects (column 2) are included. Remaining columns report estimates using the proper specifications of the gravity equation controlling for endogeneity. Coefficients on control variables are found significant and all have the expected sign-geographical distance impedes bilateral trade, as well as the fact to be landlocked, whereas sharing a common border, language or colonial history increases trade. 9

Concerning our variables of interest, results are surprisingly diverging and large when controlling only for time fixed effects. The trade creating effect of regional integration range from a $\mathrm{e}^{0.09}-1=9 \%$ increase for PAs to a $232 \%$ for PoAs and a $282 \%$ for CUs. When country-and-time fixed effects are included (column 2), coefficients on RTAs largely decrease, and the coefficient on CM becomes insignificant. In this specification, political agreements exhibit the largest coefficient, corresponding to a $101 \%$ increase in bilateral trade. The ranking as well as the size of coefficients cast doubts on the validity of these results.

First-differencing the data or introducing bilateral fixed effects to account for self-selection into RTAs reduces the coefficients on PoAs and shallow RTAs but increases the coefficient on CMs, which turns significant. Hence, the endogeneity bias arising from unobserved variables affecting bilateral trade flows and RTA membership differs according to the kind of RTA considered. It suggests that different kinds of country pairs choose to form different kinds of RTAs, and that the unobservable factors affecting the likelihood of RTA formation also affect trade, but unevenly according to the depth of integration.

Results do show a robust significant average treatment effect of all kinds of RTAs on bilateral trade, except that of political agreements in the first-differenced specification. In the preferred specification (column 4), a CM is associated with a current increase of $30 \%$ in bilateral trade, to be compared to $34 \%$ for a CU or a free trade area, and $18 \%$ for a PA. When RTAs are considered jointly (column 5),

\footnotetext{
${ }^{9}$ Results remain qualitatively similar when the coefficient on GDPs is constrained to 1 , i.e. when the dependent variable is replaced by $\ln T_{i j t}=\left(\ln \frac{i m p_{i j t}}{\operatorname{GDP}_{i t} \mathrm{GDP}_{j t}}+\ln \frac{\text { imp }_{i t}}{\mathrm{GDP}_{i t} \mathrm{GDP}_{j t}}\right) / 2$.
} 


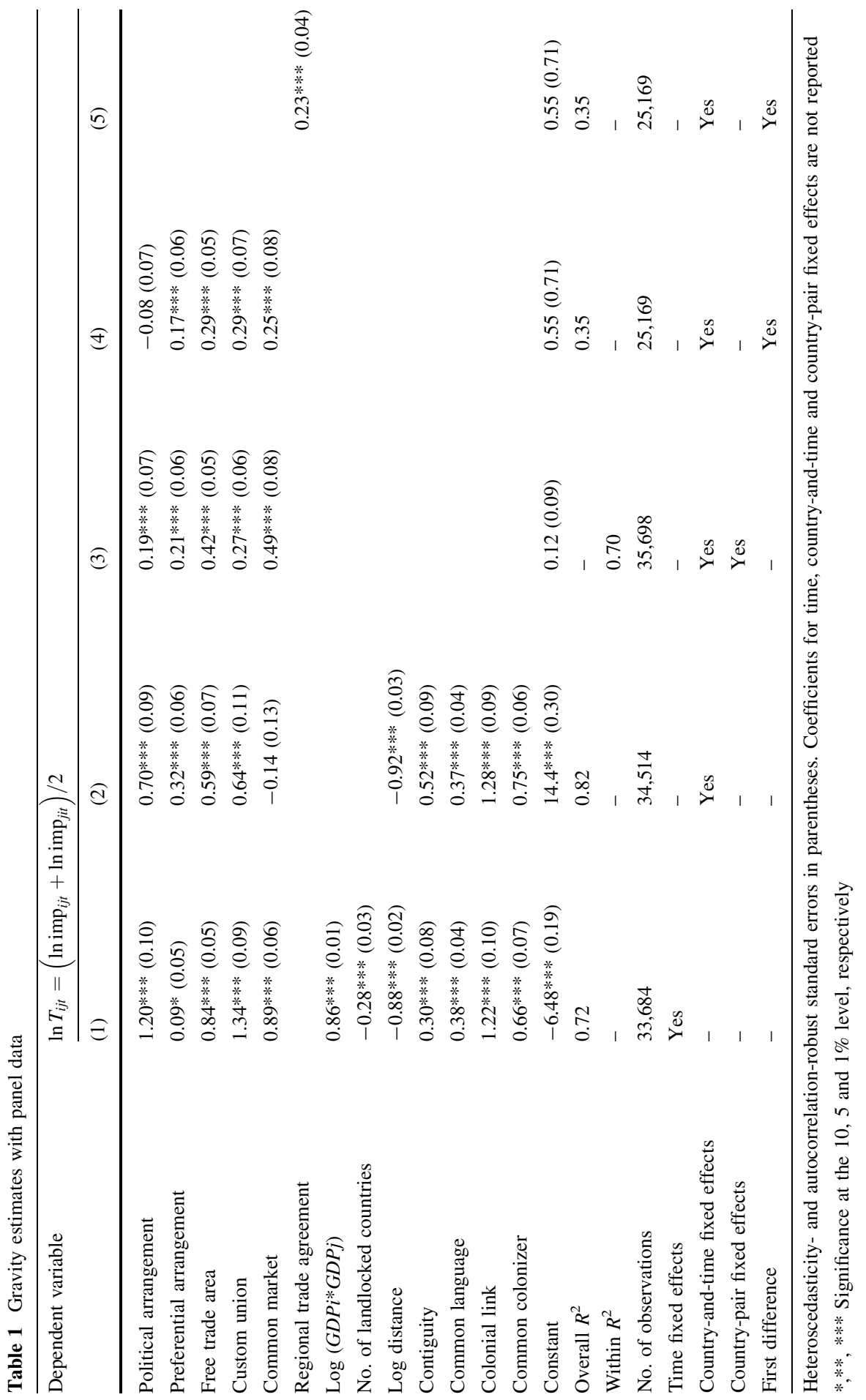


regional integration is found to increase intra-zone trade by $26 \%$. These results are in line with the $36 \%$ contemporaneous effect found by Baier and Bergstrand (2007), on a different sample of countries and a restricted sample of RTAs excluding PAs.

A third important result is that the average treatment effects of all kinds of RTAs providing trade preferences to their members are statistically similar. Indeed, the hypothesis of equality of coefficients on the different kinds of RTAs (PoAs excluded) cannot be rejected, jointly and separately, at traditional level of significance in first-differenced specification, and the equality of coefficients on FTA and CM cannot be rejected in the fixed effect specification (see Table 2). If any, only PAs could be understood as a first step of integration providing for less trade integration than other more "integrated" agreements. This suggests that the institutional design of regional agreements does not determine their ability to create trade among members. The effect on trade of forming an FTA, a CU or a CM is not statistically different, but different country pairs form different RTAs.

This rather counterintuitive result is not so surprising in the light of the lack of theory actually predicting that an FTA would systematically reduce more transactions costs on intra-regional trade than a CU. It suggests that the choice of countries to create different forms of RTAs is not only related to trade issues. Notwithstanding, the fact that if similar country pairs were to enter a CU, an FTA or a CM, the effect on bilateral trade would be similar does not preclude any trade related determinants of the choice of RTAs. The fact that unobserved heterogeneity affects differently country pairs entering different kinds of RTAs suggests that gains from regional integration could differ according to characteristics of both member countries and specific trade agreements. These results could have interesting implications to explain the diverging effects of RTAs found in the literature (Ghosh and Yamarik 2004a). Overall, empirical evidence provided in this paper points out

Table 2 Wald tests of equality of coefficients on PA, FTA, CU and CM

\begin{tabular}{|c|c|c|c|c|c|}
\hline Specification & All coeff. & PA-FTA & FTA-CU & FTA-CM & CU-CM \\
\hline \multicolumn{6}{|l|}{ Basic specification } \\
\hline Fixed effect & $4.77 * * *$ & $8.75^{* * *} *$ & $4.10^{* *}$ & 0.62 & $8.27 * * *$ \\
\hline First difference & 1.09 & 2.61 & 0.00 & 0.15 & 0.25 \\
\hline \multicolumn{6}{|c|}{ With lags (total ATE) } \\
\hline Fixed effect & $3.57 * *$ & $9.82 * * *$ & 2.06 & 0.05 & 1.63 \\
\hline First difference & $2.75 * *$ & $5.56^{* *}$ & 0.34 & $2.98 *$ & 1.66 \\
\hline \multicolumn{6}{|c|}{ Without bilateral RTAs } \\
\hline Fixed effect & $2.31 *$ & 2.55 & 1.69 & 0.30 & $5.33 * *$ \\
\hline First difference & 0.72 & 1.32 & 0.00 & 0.20 & 0.39 \\
\hline \multicolumn{6}{|l|}{ 1990-2000 } \\
\hline Fixed effect & 0.90 & 0.72 & 2.46 & 1.78 & 0.17 \\
\hline First difference & 1.62 & $3.09 *$ & 0.16 & 0.01 & 0.41 \\
\hline
\end{tabular}

$*$, **, *** Null hypothesis of equality of coefficients can be rejected at the 10, 5 and $1 \%$ level, respectively 
that creating a free trade area, a CU or a CM has a similar effect on bilateral trade, but that different country pairs tend to create different kind of RTAs.

\section{Robustness analysis}

In this section, I test for the sensitivity of the above results to several sources of bias and perturbations, namely lagged effects, alternative sample of years and countries and definition of RTAs, and time-varying missing variables.

\subsection{Lagged effects}

Regional trade agreements generally plan a phase-in period during which provisions of the treaty are implemented gradually. They are thus likely to have lagged effects on trade, as all provisions of the agreement are generally implemented over a 5- to 10 -year period of time. For instance, the treaty of Rome creating the European Economic Community in 1958 projected the full implementation of the CU in 1968. The date of entry into force of a RTA does not correspond to its full implementation, so that our membership dummy variable, which is coded 1 from the date of entry into force of the agreement, cannot account for this phase-in period. One-periodlagged variables of each of the dummies measuring RTA membership are thus added to our specification. Since some kinds of RTAs, notably CMs, have largely been created in the 1990s, we cannot account for further lags because the time span of our data set is not large enough.

Results, presented in columns (1) and (2) of Table 3, clearly confirm previous findings. All categories of RTAs, except political agreements in the first-differenced specification, significantly increase bilateral trade from their date of entry into force. Moreover, FTAs and CUs in the fixed-effect specification exhibit an additional effect after 5 years. The total average treatment effect after 5 years is 68 and $51 \%$ in the fixed-effect and first-differenced specifications, respectively, for FTAs, and 48 and $46 \%$ for CUs. The coefficient on the lagged term of CM membership is however not statistically significant. The fact that CMs have been preceded by CUs or bilateral FTAs is likely to explain the lack of significance of the lagged variable. The contemporary average treatment effect of a CM is nevertheless slightly larger that in our basic specification, namely 72 and $34 \%$ in the fixed-effect and firstdifferenced specifications, respectively. Again, the hypothesis of equality of coefficients on FTA, CU and CM cannot be rejected at traditional level of significance (see Table 2).

\subsection{Samples of RTAs and years}

Another source of heterogeneity is related to the definition of RTAs. Indeed, bilateral agreements are likely to differ substantially from regional agreements (including three or more partners) in terms of determinants as well as the institutional framework they provide. Columns (3) and (4) of Table 3 test for the robustness of the results of the previous section to the exclusion of bilateral RTAs in 


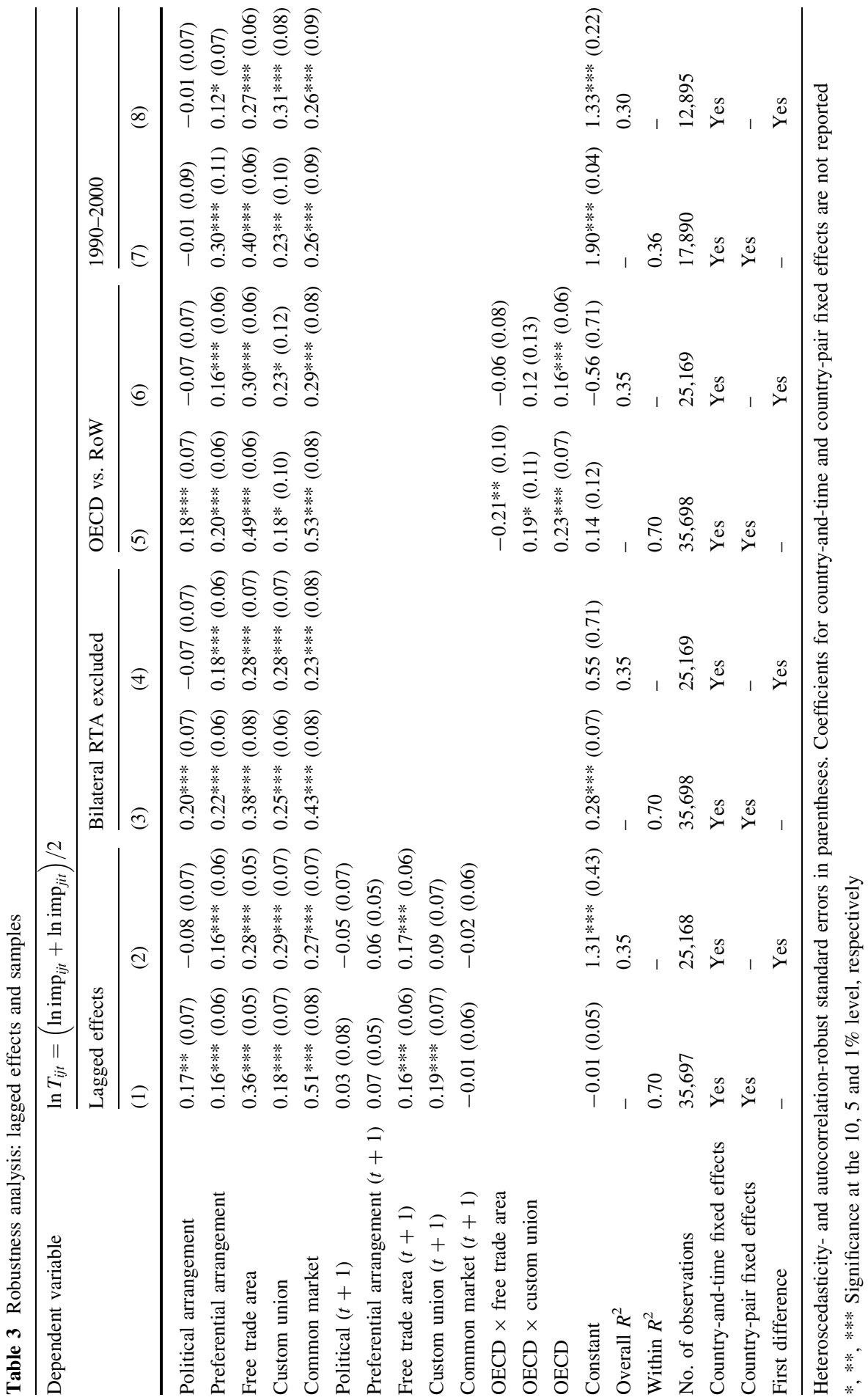


our explaining variables. Results remain qualitatively similar: all kinds of RTAs are found to increase intra-zone trade, but this trade creating effect does not statistically differ according to the depth of integration.

Another source of heterogeneity within each category of RTAs may be related to country members. The specificities of the RTAs, and their effect on intra-regional trade, could indeed differ according to the level of wealth of member countries for each kind of agreement. In order to test the sensitivity of my results to this kind of heterogeneity, I include interaction terms between RTA membership dummies and a dummy equal to one when both countries are members of the OECD, as a proxy for pairs of rich countries. Since CMs have been created only among OECD members and preferential agreements are entitled only among developing countries, I add interactions with the FTA and CU dummies to the basic specification. Results are presented in columns (5) and (6) of Table 3. Interactions variables are not significant in the first-differenced specification, but are in the fixed-effect specification. The latter suggests that FTAs are less trade creating and that CUs are more trade creating among OECD countries; the coefficients on FTA among non-OECD members, CU among OECD members and CM are nevertheless not statistically different in the fixed-effect specification. In the specification in firstdifference, the results remain qualitatively similar.

In addition, both the explosion of the number and coverage of RTAs (see Fig. 1) and the increased depth of agreements such as the EU since the 1990s have led some scholars to qualify this wave of regionalism as new regionalism. In this respect, it could be argued that determinants and characteristics of new RTAs signed in the 1990s could differ from previous agreements. In order to test for any specificity of this period, Eq. 1 is estimated on a sample restricted to the 1990s. Results are presented in columns (7) and (8) of Table 3. The average treatment effect of each kind of RTAs is similar when estimated only over the 1990s and on the whole year sample. Results diverge only concerning PAs, for which the coefficient is slightly larger in the fixed-effect specification and insignificant in the differenced specification. Anyway, Wald tests of equality of coefficients on all categories of RTAs providing for trade preferences are not rejected in both specifications (see Table 2), confirming that the treatment effect of RTAs on bilateral trade does not differ according to their form.

\subsection{Time-varying country pair-specific determinants of trade}

Country-and-time dummies included in all our specifications control for all country characteristics likely to affect trade, time-invariant (landlocked countries, area, island,...) as well as time-varying determinants (GDP, GDP per capita, economic governance, transport infrastructure, specialization, external tariffs as well as any determinant related to preferential market access such as the number of RTAs in which countries take part). Moreover, country-pair fixed effects (or first-differencing the data) account for dyadic determinants of trade (distance, contiguity, cultural proximity, common language...) and country-pair heterogeneity that are constant over time. Still, an endogeneity bias could arise because of omitted variables varying over time and affecting both the likelihood to enter one category of RTAs 
Table 4 Robustness analysis: time-varying country pair-specific variables

\begin{tabular}{|c|c|c|c|c|}
\hline \multirow[t]{3}{*}{ Dependent variable } & \multicolumn{4}{|c|}{$\ln T_{i j t}=\left(\ln \mathrm{imp}_{i j t}+\ln \mathrm{imp}_{j i t}\right) / 2$} \\
\hline & \multicolumn{2}{|c|}{ Interstate political affinity } & \multicolumn{2}{|c|}{ Exchange rate volatility } \\
\hline & (1) & (2) & (3) & (4) \\
\hline Political arrangement & $0.19 * *(0.09)$ & $-0.03(0.08)$ & $0.18 * *(0.09)$ & $-0.05(0.08)$ \\
\hline Preferential arrangement & $0.21 * * *(0.06)$ & $0.25 * * *(0.06)$ & $0.22 * * *(0.07)$ & $0.11(0.08)$ \\
\hline Free trade area & $0.31 * * *(0.08)$ & $0.27 * * *(0.07)$ & $0.29 * * *(0.06)$ & $0.20 * * *(0.05)$ \\
\hline Custom union & $0.31 * * *(0.07)$ & $0.29 * * *(0.08)$ & $0.27 * * *(0.07)$ & $0.31 * * *(0.07)$ \\
\hline Common market & $0.52 * * *(0.09)$ & $0.26 * * *(0.09)$ & $0.63 * * *(0.08)$ & $0.19 * * *(0.08)$ \\
\hline UN vote correlation & $0.27 * * *(0.06)$ & $0.06(0.05)$ & & \\
\hline No. of peaceful years & $-0.00(0.00)$ & $0.00(0.00)$ & & \\
\hline Exchange rate volatility & & & $-0.04(0.04)$ & $-0.02(0.06)$ \\
\hline Constant & $0.23 * * *(0.09)$ & $-0.77 * *(0.31)$ & $0.82 * * *(0.05)$ & $0.82(3.21)$ \\
\hline Overall $R^{2}$ & - & 0.38 & - & 0.36 \\
\hline Within $R^{2}$ & 0.72 & - & 0.76 & - \\
\hline No. of observations & 25687 & 17297 & 21891 & 15187 \\
\hline Country-and-time fixed effects & Yes & Yes & Yes & Yes \\
\hline Country-pair fixed effects & Yes & - & Yes & - \\
\hline First difference & - & Yes & - & Yes \\
\hline
\end{tabular}

Heteroscedasticity- and autocorrelation-robust standard errors in parentheses. Coefficients for countryand-time and country-pair fixed effects are not reported

$*, * *, * * *$ Significance at the 10,5 and $1 \%$ level, respectively

and bilateral trade flows. In this section, I control for two such potential endogeneity issues: interstate political affinities and variations in bilateral real exchange rates.

Trade policy is considered by many countries as an instrument of foreign policy. For instance, Lederman and Ozden (2007) argue that the United States grant trade preferences, notably by signing bilateral FTAs, largely on a geopolitical basis. Maintaining good diplomatic relations is therefore likely to facilitate the negotiation and signing of an RTA. Besides, having good interstate political relations reduces the risk related to international trade and thus foster trade flows. Two variables are used as proxy for interstate affinity: the vote correlation in the United Nations General Assembly, taken from The Affinity of Nations: Similarity of State Voting Positions in the UN General Assembly developed by Erik Gartzke, ${ }^{10}$ and the number of peaceful years between two countries, computed from the Correlates of War Project. ${ }^{11}$ Results presented in Table 4 are mixed: UN vote correlation exerts a positive and significant effect on bilateral trade only in the fixed-effect specification, whereas having peaceful relations has no significant effect on bilateral trade flows. Nevertheless, controlling for political affinity does not alter our results on the equality of coefficients. Coefficients on $\mathrm{CU}$ and $\mathrm{CM}$ are slightly larger and the

\footnotetext{
${ }_{10}$ http://dss.ucsd.edu/ egartzke/.

${ }^{11}$ http://cow2.la.psu.edu/.
} 
coefficient on FTA is lower in the fixed-effects specification, but only the coefficient on PA is affected in the differenced specification.

The volatility of nominal exchange rates create risks on international transaction and uncertainty at the firm level; it is thus likely that economic agents would be discouraged from trading with countries exhibiting a large exchange rate volatility with their home country. By reducing risks related to exchange rate variations, fixed exchange rate systems would then increase the volume of bilateral trade. At the same time, common currencies or monetary systems limiting currency fluctuations are mostly established on a regional basis. The volatility of exchange rates could thus be correlated to trade flows and the decision to create a RTA. To control for this potential omitted variable bias, I include a variable of exchange rate variability between countries $i$ and $j$ in year $t$, denoted $\operatorname{vol}_{i j t}$ in (1). Following Tenreyro (2007), the exchange rate variability is measured as the standard deviation of the first difference of (the logarithm of) the monthly exchange rate between the two countries:

$$
\operatorname{vol}_{i j t}=\mathrm{SD}\left(\ln \left(e_{i j t, m}\right)-\ln e\left({ }_{i j t, m-1}\right)\right), \quad m=1, \ldots, 12
$$

where $e_{i j t, m}$ is the monthly bilateral nominal exchange rate.

Data come from the IMF's International Financial Statistics and Reuters, provided by EcoWin Financial. The availability of data on monthly nominal exchange rates noticeably reduces the sample. Results are presented in columns (3) and (4) of Table 4. The coefficient on exchange rate volatility is negative but not significant in both specifications, which is in line with the ambiguous effect put forward in the literature (Tenreyro 2007). Turning to our variables of interest, results remain consistent with the benchmark estimates. It is worth noting that the fact that the coefficients on PA, FTA and CM are found slightly lower in the firstdifferenced specification, and the CM coefficient slightly larger in the fixed-effect specification, is related to the restricted sample rather than the inclusion of the variable of exchange rate volatility. ${ }^{12}$ Again, the results on the equality of coefficients basically hold when controlling for the volatility of bilateral exchange rates.

The results presented in this paper are therefore robust to a number of robustness checks regarding lagged effects, the definition of RTAs, the period and countries considered, and the inclusion of time varying determinants of trade and RTA formation.

\section{Conclusion}

This paper investigated whether the form of RTAs matters concerning their effect on trade, in a gravity type framework differentiating four categories of RTAs according to the usual taxonomy initiated by Balassa (1961): PAs, FTAs, CUs and CMs. It shows a significant and positive average treatment effect of all kinds of RTAs providing trade preferences to their members on bilateral trade. However,

\footnotetext{
12 Estimating the baseline model on this restricted sample yields the same results.
} 
once self-selection into agreements is controlled for, their trade creation effect does not statistically differ according to the depth of the RTA: creating a FTA, a CU or a $\mathrm{CM}$ has a similar impact on trade among members. Different pairs of countries thus create different kinds of RTAs.

The latter result emphasizes that the different forms of regional integration do not reflect any larger potential trade creation effect. It suggests that the depth of RTAs should not only be defined on the criteria of their ability to foster trade. Instead, it should also be regarded as a question of political or institutional integration.

In addition, these results support a "market for regionalism" view of RTAs, where different country pairs choose to create different kinds of RTAs. Further work is nevertheless necessary to understand what drives gains from preferential trade integration and to highlight the determinants of successful integration processes according to both RTAs' and member countries' characteristics.

Acknowledgments I thank Harmen Lehment, Thierry Mayer and an anonymous referee. I also thank Jeffrey Bergstrand for helpful suggestions on an earlier version of this paper.

\section{Appendix: Regional trade agreements (1960-2000)}

\begin{tabular}{|c|c|c|}
\hline Name & Official dates & $\begin{array}{l}\text { Actual dates } \\
\text { (5-year intervals) }\end{array}$ \\
\hline \multicolumn{3}{|l|}{ Common markets } \\
\hline Benelux & 1961 & $(1965-2000)$ \\
\hline European Union (EU) & 1992 & $(1995-2000)$ \\
\hline \multicolumn{3}{|l|}{ Customs unions } \\
\hline Eurasian Economic Community & 1997 & $(2000-2000)$ \\
\hline Equatorial Customs Union & 1959-1965 & $(1960-1965)$ \\
\hline Economic and Monetary Community of Central Africa & 1994 & $(1995-2000)$ \\
\hline Mano River Union & 1973 & $(1975-2000)$ \\
\hline Customs Union of West African States & 1960-1966 & $(1960-1965)$ \\
\hline West African Economic and Monetary Union & 1998 & $(2000-2000)$ \\
\hline East African Community & 1967-1977 & $(1970-1975)$ \\
\hline Benelux & $1947-1960$ & $(1960-1960)$ \\
\hline European Communities (EC) & 1958-1991 & $(1960-1990)$ \\
\hline Customs Union EU-Malta & 1971 & $(1975-2000)$ \\
\hline Customs Union EU-Cyprus & 1973 & $(1975-2000)$ \\
\hline Customs Union EU-Turkey & 1996 & $(2000-2000)$ \\
\hline Customs Union Czech Republic-Slovakia & 1993 & $(1995-2000)$ \\
\hline Southern Common Market (MERCOSUR) & 1991 & $(1995-2000)$ \\
\hline Central American Common Market (CACM) & 1993 & $(1995-2000)$ \\
\hline Andean Customs Union ${ }^{\mathrm{a}}$ & 1995 & $(1995-2000)$ \\
\hline Caribbean Community and Common Market (CARICOM) & 1973 & $(1975-2000)$ \\
\hline
\end{tabular}


Appendix continued

\begin{tabular}{lll}
\hline Name & Official dates & $\begin{array}{l}\text { Actual dates } \\
\text { (5-year intervals) }\end{array}$ \\
\hline
\end{tabular}

Free trade agreements

Closer Trade Relations Trade Agreement

1983

(1985-2000)

Commonwealth of Independent States

1995

(1995-2000)

Papua New Guinea and Australia Trade and Commercial

1977

(1980-2000)

Baltic Free Trade Area

(1995-2000)

Central European Free Trade Agreement

1994

(1995-2000)

European Economic Area

1993

(1995-2000)

European Free Trade Agreement (EFTA)

1994

(1960-2000)

Group of Three

1960

(1995-2000)

North American Free Trade Agreement (NAFTA)

1995

(1995-2000)

South African Development Community

1994

(2000-2000)

Central American Common Market

2000

(1965-1975)

Andean Free Trade Area ${ }^{a}$

1961-1975

$(2000-2000)^{\mathrm{a}}$

Caribbean Free Trade Area

1993

(1970-1970)

Armenia-Moldova

1968-1972

(1995-2000)

Armenia-Russia

1995

(1995-2000)

Armenia-Turkmenistan

1993

(2000-2000)

Armenia-Ukraine

1996

(2000-2000)

Bulgaria-Turkey

1996

(2000-2000)

Canada-Chile

1999

(2000-2000)

Canada-Israel

1997

(2000-2000)

CARICOM-Dominican Republic

1997

(2000-2000)

Czech Republic-Estonia

1998

(2000-2000)

Czech Republic-Israel

1998

(2000-2000)

Czech Republic-Latvia

1997

(2000-2000)

Czech Republic-Lithuania

1997

(2000-2000)

Czech Republic-Turkey

1997

(2000-2000)

EU-Algeria

1998

(2000-2000)

EU-Bulgaria

1998

(1995-2000)

EU-Czech Republic

1994

(1995-2000)

EU-Egypt

1992

(1995-2000)

EU-Estonia

1977

(1995-2000)

EU-Hungary

1995

(1995-2000)

EU-Israel

1992

(2000-2000)

EU-Latvia

2000

(1995-2000)

EU-Lithuania

1995

(1995-2000)

EU-Morocco

1995

(2000-2000)

EU-Norway

2000

(1975-1990)

EU-Poland

1973-1993

(1995-2000)

EU-Romania

1992

(1995-2000) 
Appendix continued

\begin{tabular}{|c|c|c|}
\hline Name & Official dates & $\begin{array}{l}\text { Actual dates } \\
\text { (5-year intervals) }\end{array}$ \\
\hline EU-Slovakia & 1992 & $(1995-2000)$ \\
\hline EU-Slovenia & 1997 & $(2000-2000)$ \\
\hline EU-South Africa & 2000 & $(2000-2000)$ \\
\hline EU-Switzerland & 1973 & $(1975-2000)$ \\
\hline EU-Syria & 1977 & $(1980-2000)$ \\
\hline EU-Tunisia & 1998 & $(2000-2000)$ \\
\hline EFTA-Bulgaria & 1993 & $(1995-2000)$ \\
\hline EFTA-Czech Republic & 1992 & $(1995-2000)$ \\
\hline EFTA-Estonia & 1996 & $(2000-2000)$ \\
\hline EFTA-Hungary & 1993 & $(1995-2000)$ \\
\hline EFTA-Israel & 1993 & $(1995-2000)$ \\
\hline EFTA-Latvia & 1996 & $(2000-2000)$ \\
\hline EFTA-Lithuania & 1996 & $(2000-2000)$ \\
\hline EFTA-Morocco & 1999 & $(2000-2000)$ \\
\hline EFTA-Poland & 1993 & $(1995-2000)$ \\
\hline EFTA-Romania & 1993 & (1995-2000) \\
\hline EFTA-Slovakia & 1992 & $(1995-2000)$ \\
\hline EFTA-Slovenia & 1995 & $(1995-2000)$ \\
\hline EFTA-Turkey & 1992 & $(1995-2000)$ \\
\hline Estonia-Turkey & 1998 & $(2000-2000)$ \\
\hline Estonia-Ukraine & 1996 & $(2000-2000)$ \\
\hline Georgia-Armenia & 1998 & $(2000-2000)$ \\
\hline Georgia-Azerbaijan & 1996 & $(2000-2000)$ \\
\hline Georgia-Kazakhstan & 1999 & $(2000-2000)$ \\
\hline Georgia-Russia & 1994 & $(1995-2000)$ \\
\hline Georgia-Turkmenistan & 2000 & $(2000-2000)$ \\
\hline Georgia-Ukraine & 1996 & $(2000-2000)$ \\
\hline Hungary-Israel & 1998 & $(2000-2000)$ \\
\hline Hungary-Latvia & 2000 & $(2000-2000)$ \\
\hline Hungary-Lithuania & 2000 & $(2000-2000)$ \\
\hline Hungary-Turkey & 1998 & $(2000-2000)$ \\
\hline Kyrgyzstan-Armenia & 1995 & $(1995-2000)$ \\
\hline Kyrgyzstan-Kazakhstan & 1995 & $(1995-2000)$ \\
\hline Kyrgyzstan-Moldova & 1996 & $(2000-2000)$ \\
\hline Kyrgyzstan-Russia & 1993 & (1995-2000) \\
\hline Kyrgyzstan-Ukraine & 1998 & $(2000-2000)$ \\
\hline Kyrgyzstan-Uzbekistan & 1998 & $(2000-2000)$ \\
\hline Latvia-Turkey & 2000 & $(2000-2000)$ \\
\hline Lithuania-Turkey & 1998 & $(2000-2000)$ \\
\hline MERCOSUR-Chile & 1996 & $(2000-2000)$ \\
\hline MERCOSUR-Bolivia & 1996 & $(2000-2000)$ \\
\hline
\end{tabular}


Appendix continued

\begin{tabular}{|c|c|c|}
\hline Name & Official dates & $\begin{array}{l}\text { Actual dates } \\
\text { (5-year intervals) }\end{array}$ \\
\hline Mexico-Israel & 2000 & $(2000-2000)$ \\
\hline Mexico-Costa Rica & 1995 & $(1995-2000)$ \\
\hline Mexico-Bolivia & 1995 & $(1995-2000)$ \\
\hline Mexico-Nicaragua & 1998 & $(2000-2000)$ \\
\hline Poland-Israel & 1998 & $(2000-2000)$ \\
\hline Poland-Latvia & 1999 & $(2000-2000)$ \\
\hline Poland-Lithuania & 1997 & $(2000-2000)$ \\
\hline Poland-Turkey & 2000 & $(2000-2000)$ \\
\hline Romania-Turkey & 1998 & $(2000-2000)$ \\
\hline Slovakia-Estonia & 1998 & $(2000-2000)$ \\
\hline Slovakia-Israel & 1997 & $(2000-2000)$ \\
\hline Slovakia-Latvia & 1997 & $(2000-2000)$ \\
\hline Slovakia-Lithuania & 1997 & $(2000-2000)$ \\
\hline Slovakia-Turkey & 1998 & $(2000-2000)$ \\
\hline Slovenia-Estonia & 1997 & $(2000-2000)$ \\
\hline Slovenia-Israel & 1998 & $(2000-2000)$ \\
\hline Slovenia-Latvia & 1996 & $(2000-2000)$ \\
\hline Slovenia-Lithuania & 1997 & $(2000-2000)$ \\
\hline United States of America-Israel & 1985 & $(1985-2000)$ \\
\hline United States of America-Canada & 1989-1993 & $(1990-1990)$ \\
\hline India-Bhutan & 1995 & $(1995-2000)$ \\
\hline India-Nepal & 1996 & $(2000-2000)$ \\
\hline India-Sri Lanka & 1998 & $(2000-2000)$ \\
\hline \multicolumn{3}{|l|}{ Preferential arrangements } \\
\hline $\begin{array}{l}\text { Protocol Relating to Trade Negotiations among } \\
\text { Developing Countries (PTN) }\end{array}$ & 1973 & $(1975-2000)$ \\
\hline $\begin{array}{l}\text { Global System of Trade Preferences among Developing } \\
\text { Countries (GSTP) }\end{array}$ & 1989 & $(1990-2000)$ \\
\hline Tripartite agreement & 1968 & $(1970-2000)$ \\
\hline Economic Cooperation Organization & 1992 & $(1995-2000)$ \\
\hline Gulf Cooperation Council (GCC) & 1984 & $(1985-2000)$ \\
\hline $\begin{array}{l}\text { South Pacific Regional Trade and Economic Cooperation } \\
\text { Agreement }\end{array}$ & 1981 & $(1985-2000)$ \\
\hline Melanesian Spearhead Group & 1993 & $(1995-2000)$ \\
\hline Council for Mutual Economic Assistance & 1949-1990 & $(1960-1990)$ \\
\hline ASEAN Free Trade Agreement & 1992 & $(1995-2000)$ \\
\hline Bangkok Agreement & 1976 & $(1980-2000)$ \\
\hline South Asian Preferential Trade Agreement & 1995 & $(1995-2000)$ \\
\hline West African Economic Community & 1973-1997 & $(1975-1995)$ \\
\hline Common Market for Eastern and Southern Africa & 1994 & $(1995-2000)$ \\
\hline East African Cooperation & 2000 & $(2000-2000)$ \\
\hline
\end{tabular}


Appendix continued

\begin{tabular}{|c|c|c|}
\hline Name & Official dates & $\begin{array}{l}\text { Actual dates } \\
\text { (5-year intervals) }\end{array}$ \\
\hline Latin American Free Trade Association & $1961-1980$ & $(1965-1980)$ \\
\hline Latin American Integration Association & 1993 & $(1995-2000)$ \\
\hline Andean Community ${ }^{\mathrm{a}}$ & $1988-1997$ & $(1990-1995)^{\mathrm{a}}$ \\
\hline CARICOM-Colombia & 1995 & $(1995-2000)$ \\
\hline CARICOM-Venezuela & 1993 & $(1995-2000)$ \\
\hline Laos-Thailand & 1991 & $(1995-2000)$ \\
\hline Chile-Peru & 1998 & $(2000-2000)$ \\
\hline Chile-Bolivia & 1993 & $(1995-2000)$ \\
\hline Chile-Colombia & 1994 & $(1995-2000)$ \\
\hline Chile-Venezuela & 1993 & $(1995-2000)$ \\
\hline \multicolumn{3}{|l|}{ Political agreements } \\
\hline Regional Cooperation for Development & 1965-1979 & $(1965-1975)$ \\
\hline Arab Maghreb Union & 1989 & $(1990-2000)$ \\
\hline $\begin{array}{l}\text { South African Development Coordination Conference } \\
\text { (SADC) }\end{array}$ & 1980-1999 & $(1980-1995)$ \\
\hline Cross Border Initiative & 1990 & $(1990-2000)$ \\
\hline Association of South East Asian Nations & 1967 & $(1970-2000)$ \\
\hline South Asian Association for Regional Cooperation & 1985 & $(1985-2000)$ \\
\hline Asian Pacific Cooperation & 1989 & $(1990-2000)$ \\
\hline
\end{tabular}

Source: WTO (http://www.wto.org/english/tratop_e/region_e/region_e.htm), Foroutan (1993, 1998), Langhammer and Hiemenz (1990), Frankel (1997), Machlup (1977) and other public sources

a Peru entered the Andean Free Trade Area only in 1997, and did not join the Andean Customs Union until 2004

\section{References}

Anderson, J. E., \& Marcouiller, D. (2002). Insecurity and the pattern of trade: An empirical investigation. The Review of Economics and Statistics, 84(2), 345-352.

Anderson, J. E., \& van Wincoop, E. (2003). Gravity with gravitas: A solution to the border puzzle. The American Economic Review, 93(1), 170-192.

Anderson, J. E., \& van Wincoop, E. (2004). Trade costs. Journal of Economic Literature, XLII(3), 691751.

Baier, S., \& Bergstrand, J. (2004a). Do free trade agreements actually increase members' international trade? Manuscript.

Baier, S. L., \& Bergstrand, J. H. (2004b). Economic determinants of free trade agreements. Journal of International Economics, 64(1), 29-64.

Baier, S. L., \& Bergstrand, J. H. (2007). Do free trade agreements actually increase members' international trade? Journal of International Economics, 71(1), 72-95.

Balassa, B. (1961). Towards a theory of economic integration. Kyklos, 16, 1-17.

Baldwin, R., \& Taglioni, D. (2006). Gravity for dummies and dummies for gravity equations. NBER Working Paper 12516, Cambridge, MA.

Blomberg, S. B., \& Hess, G. D. (2006). How much does violence tax trade? The Review of Economics and Statistics, 88(4), 599-612.

Carrère, C. (2006). Revisiting the effects of regional trade agreements on trade flows with proper specification of the gravity model. European Economic Review, 50(2), 223-247. 
Feenstra, R. C. (2004). Advanced international trade: Theory and evidence. Princeton: Princeton University Press.

Fiorentino, R. V., Verdeja, L., \& Toqueboeuf, C. (2007). The changing landscape of regional trade agreements: 2006 update. World Trade Organization discussion paper no 12, Geneva.

Foroutan, F. (1993). Regional integration in Sub-Saharan Africa: Past experience and future prospects. In J. de Melo \& A. Panagariya (Eds.), New dimensions in regional integration. Cambridge: Cambridge University Press.

Foroutan, F. (1998). Does membership in an FTA make a country more or less protectionist? The World Economy, 21(3), 305-335.

Frankel, J. A. (1997). Regional trading blocs. Washington: Institute for International Economics.

Ghosh, S., \& Yamarik, S. (2004a). Are regional trading arrangements trade creating? An application of extreme bounds analysis. Journal of International Economics, 63(2), 369-395.

Ghosh, S., \& Yamarik, S. (2004b). Does trade creation measure up? A reexamination of the effects of regional trading arrangements. Economics Letters, 82(2), 213-219.

Kandogan, Y. (2008). Consistent estimates of regional blocs trade effects. Review of International Economics, 16(2), 301-314.

Krueger, A. O. (1997). Free trade agreements versus customs unions. Journal of Development Economics, 54(1), 169-187.

Langhammer, R. J., \& Hiemenz, U. (1990). Regional integration among developing countries: Opportunities, obstacles and options. Tübingen: Mohr.

Lederman, D., \& Ozden, C. (2007). Geopolitical interests and preferential access to U.S. markets. Economics and Politics, 19(2), 235-258.

Machlup, F. (1977). A history of thought on economic integration, chap. 5. London: Macmillan.

Magee, C. S. (2003). Endogenous preferential trade agreements: An empirical analysis. Contributions to Economic Analysis \& Policy, 2(1).

Martin, P., Mayer, T., \& Thoenig, M. (2008). Make trade not war? The Review of Economic Studies, 75(3), 865-900.

Tenreyro, S. (2007). On the trade impact of nominal exchange rate volatility. Journal of Development Economics, 82(2), 485-508.

Vicard, V. (2008). Trade, conflicts and political integration: Explaining the heterogeneity of regional trade agreements. CES Working Papers 2008.22.

Wooldridge, J. M. (2003). Introductory econometrics: A modern approach (2nd ed.). Cincinnati, OH: Southwestern College Publishing.

World Bank (2005) Global economic prospects 2005: Trade, regionalism and development. Washington, DC: World Bank. 